\title{
Statyba
}

\section{THE BOLT-WITH-A CRACK SHAKEDOWN ESTIMATION BY THE METHOD OF ADDITIONAL LOAD}

\section{Leonavičius \& M. Šukšta}

To cite this article: M. Leonavičius \& M. Šukšta (1997) THE BOLT—WITH—A CRACK

SHAKEDOWN ESTIMATION BY THE METHOD OF ADDITIONAL LOAD, Statyba, 3:9, 74-77, DOI: 10.1080/13921525.1997.10531674

To link to this article: https://doi.org/10.1080/13921525.1997.10531674

曲 Published online: 26 Jul 2012.

Submit your article to this journal $₫$

Џ Article views: 42 


\section{THE BOLT - WITH - A CRACK SHAKEDOWN ESTIMATION BY THE METHOD OF} ADDITIONAL LOAD

\section{Leonavičius, M. Šukšta}

\section{Introduction}

Within some metal constructions, the bolts dimensions of flange joints and single joints are limited by general compositional requirements. Usually efforts are taken in order to amplify the prestress of such joints. Operational reliability is determined by the construction of the joint, selection of the pressing force taking into account the functional purpose of the joint, precision of the pre-stress in the course of putting together, steadiness of pre-stress under cyclic forces. In the case of strong press up to $0,8 \sigma_{y}$ (yielding stress), the working conditions can occur like those shown in Fig. 1.

In cases when plastic deformations take place on the boundary of bolt under cyclic load, its stability may be lost. In such a case the analysis of the shakedown conditions enable to define the limit values of the external effects. The comparison of the given cycle in respect of corresponding limited cycle enables us to estimate the peculiarities of the bolt load in case the infringements of shakedown conditions occur and, consequently, it is possible to specify the approximate danger of deterioration.

Generally, the law of statical shakedown (Melan's law) is formulated as a problem of mathematical programming. The solution of this

problem is rather complicated. It becomes easier because of various simplifications, but simplifications do not reduce the precision of the solution $[1,2]$. The method of "additional load" has been used for the estimation of the bolt shakedown.

\section{The shakedown zones of pin}

A bolt or a pin (see Fig. 1) as a bar of a circular cross-section is affected by constant axial force and symmetrically variable bending moment $-M^{*} \leq M \leq$ $M^{*}$. Two ways of deterioration can be observed: the bolt may loose the stability of the pressing force, if plastic deformation of variable sign occurs within the cross-section, or one-sided plastic deformation increasing with every new cycle accumulates within the cross-section. Combined plastic deterioration can also be mentioned. The limit state which characterizes the flow of the cross-section with a gap can be described by the following set of equations:

$$
\begin{aligned}
& N=\frac{d^{2}}{4}(2 \alpha+\sin 2 \alpha) \sigma_{y} ; \\
& M=\frac{d^{3}}{6}\left(\cos ^{3} \alpha-\cos ^{3} \alpha_{0}\right) \sigma_{y} .
\end{aligned}
$$
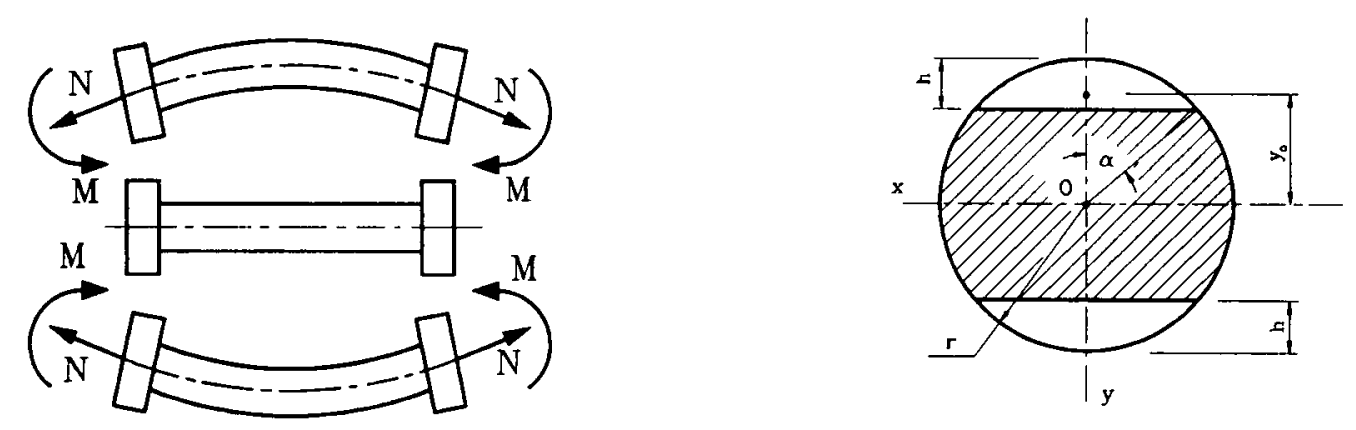

Fig. 1. Bolt and its cross-section with double-sided gap 
In this formula the angle $\alpha$ characterizes the position of the neutral line and $\sigma_{y}$ means the yield limit of the material.

The limit stresses of the cross-section weakened by the gap, i.e. the stresses causing the full flow of the cross-sections, can be expressed in the following way:

$$
\begin{aligned}
& N_{o}=\frac{d^{2}}{4}\left(2 \alpha_{o}+\sin 2 \alpha_{o}\right) \sigma_{y} \\
& M_{o}=\frac{d^{3}}{6}\left(1-\cos ^{3} \alpha_{0}\right) \sigma_{y} .
\end{aligned}
$$

The limit stresses of the unweakened circular cross-section will be as follows:

$$
N_{o}^{\bullet}=\frac{\pi d^{2}}{4} \sigma_{y} ; M_{o}^{\bullet}=\frac{d^{3}}{6} \sigma_{y} .
$$

The calculation of the limit "elastic" bending moment, i.e. the bending moment by which the maximum stress is equal to the yielding stress, is performed in such a way:

$$
M_{e}=W_{x} \sigma_{y}=\frac{d^{3}}{16 \sin \alpha_{o}}\left(\alpha_{o}-\frac{\sin 4 \alpha_{o}}{4}\right) \sigma_{o} .
$$

The plastic flow with different sign under the influence of the bending moment $M^{*} \leq M \leq M^{*}$ will take place, if the bending moment reaches the elasticity limit:

$$
M=M_{e} \text { or } M / M_{e}=1 .
$$

Let us express $M_{e}$ (5) through $M_{0}$ using the expressions (3) and (4):

$$
M_{e}=\frac{3}{8} M_{o}^{\bullet}\left(\alpha_{o}-\frac{\sin 4 \alpha_{o}}{4}\right) \text {. }
$$

Hence

$$
\frac{M}{M_{o}^{\circ} 3\left(\alpha_{o}-\frac{\sin 4 \alpha_{o}}{4}\right)}=1
$$

Introducing the relative coordinate of the bending moment $m=M / M_{o}^{\bullet}$, we receive from (7):

$$
m=\frac{3\left(\alpha_{o}-\frac{\sin 4 \alpha_{o}}{4}\right)}{8}
$$

This equation describes the condition of variable flow, which can be seen in Fig. 3 as a horizontal line. In order to examine the dependence of the shakedown zone upon the gap depth, let us introduce the factor coefficient $k=h / r$. Then $\sin \alpha_{0}=(r-h) / r=1-k$.

By setting different depths $h$ of the gap, we can calculate $m$ corresponding to the condition of the flow with a variable sign. The calculation is presented in Table 1 and the results are presented in Fig. 2.

With the change of the moment the normal stresses will increase sometimes on one side of the cross-section, sometimes on the other one and this can be the cause for the accumulation of deformations. In the case when plastic deformation zone intersects the centre of the cross-section within every half-cycle, the plastic deformations will accumulate themselves at the centre and the plastic deterioration will develop progressively.

Adding an extra load $\Delta N$ to the remaining stresses which will cause the full flow of the crosssection we obtain:

$$
N+\Delta N=N_{o}
$$

The additional axial force can by expressed through the increase of the bending moment $\Delta M$ :

$$
\begin{aligned}
& \Delta N=\int_{A} \sigma d A=\int_{A} \frac{\Delta M}{I_{x}} y d A= \\
& \frac{\Delta M}{I_{x}} \int_{0}^{\alpha_{o}} \frac{d^{3}}{4} \sin \varphi \cos ^{2} \varphi d \varphi .
\end{aligned}
$$

After the increase $\Delta M=2 M^{*}$ of the maximum possible bending moment is put in and the integration as well as elementary mathematical changes are made, we obtain:

$$
\Delta N=\frac{16 M^{*}}{d} \frac{1-\frac{\cos ^{3} \alpha_{0}}{3}}{\alpha_{0}-\frac{\sin 4 \alpha_{0}}{4}} .
$$

Table 1. The shakedown zone dependence of the variable sign flow upon the depth of the gap

\begin{tabular}{|c|c|c|c|c|c|c|c|c|c|c|c|}
\hline$k$ & 0 & 0.05 & 0.1 & 0.15 & 0.2 & 0.25 & 0.3 & 0.35 & 0.4 & 0.45 & 0.5 \\
\hline$m$ & 0.589 & 0.56 & 0.511 & 0.456 & 0.398 & 0.341 & 0.287 & 0.237 & 0.191 & 0.15 & 0.115 \\
\hline
\end{tabular}




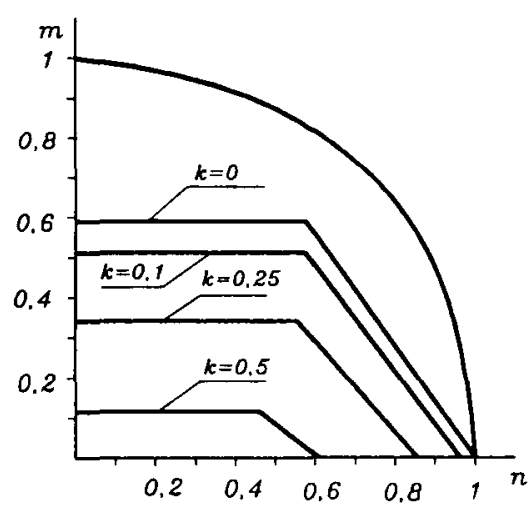

Fig. 2. The dependence of the shakedown zone area upon the depth of the gap

We shall put (11) into (9):

$$
\frac{N}{N_{o}}+\frac{16 M^{*}}{d N_{o}} \frac{1-\frac{\cos ^{3} \alpha_{o}}{3}}{\alpha_{o}-\frac{\sin 4 \alpha_{0}}{4}}=1
$$

When $N_{o}$ is expressed through $M_{o}$, we obtain:

$$
N_{o}=\frac{3 M_{o}\left(2 \alpha_{o}+\sin 2 \alpha_{o}\right)}{2 d\left(1-\cos ^{3} \alpha_{o}\right)} \text {. }
$$

and after it is put into (12), the following expression is obtained:

$$
\frac{N}{N_{o}}+\frac{M}{M_{0}} \frac{32}{3} \frac{\left(1-\frac{\cos ^{3} \alpha_{o}}{3}\right)\left(1-\cos ^{3} \alpha\right)}{\left(\alpha_{o}-\frac{\sin 4 \alpha_{o}}{4}\right)\left(2 \alpha_{o}+\sin 2 \alpha_{o}\right)}=1
$$

or

$$
n+m \frac{32}{3} \frac{\left(1-\frac{\cos ^{3} \alpha_{o}}{3}\right)\left(1-\cos ^{3} \alpha\right)}{\left(\alpha_{o}-\frac{\sin 4 \alpha_{o}}{4}\right)\left(2 \alpha_{o}+\sin 2 \alpha_{o}\right)}=1
$$

This equation expresses the condition of onesided accumulation of plastic deformations for the cross-section, within which symmetrically located gaps have develop. Low let us bring the stresses of the circular cross-section received from (2) and (3) into the formula (14):

$$
\begin{aligned}
& N_{o}=N_{o}^{\bullet}\left(2 \alpha_{o}+\sin 2 \alpha_{o}\right) / \pi ; \\
& M_{o}=M_{o}^{\bullet}\left(1-\cos ^{3} \alpha_{o}\right) .
\end{aligned}
$$

After they are put into the formula (14), we receive:

$$
\begin{aligned}
& \frac{N}{N_{o}^{*}} \frac{\pi}{\left(2 \alpha_{o}+\sin 2 \alpha_{o}\right)}+ \\
& \frac{M}{M_{0}^{*}} \frac{32}{3} \frac{\left(1-\frac{\cos ^{3} \alpha_{o}}{3}\right)}{\left(\alpha_{o}-\frac{\sin 4 \alpha_{o}}{4}\right)\left(2 \alpha_{o}+\sin 2 \alpha_{o}\right)}=1 .
\end{aligned}
$$

After corresponding marking $n=N / N_{0}^{\bullet}$ and $m=M / M_{0}^{\bullet}$ is brought into this expression, finally we receive an equation which characterizes the condition of one-sided accumulation of plastic deformations:

$$
n a+m b=1 \text {. }
$$

Following the data presented in Table 2, Fig. 2 shows the kinetics of the shakedown zone.

\section{The safety reserve of bolt}

The received data enable to identify the reserve according to the shakedown diagram Let us take one of them, for instance, when $k=0$ (Fig. 3). The point $D$ with the coordinates $m_{d}$ and $n_{d}$ in the diagram is obtained in those cases when the bar (the bolt) is loaded with the axial force $N$ and bending moment $M$. The limit point $L$ with the coordinates $m_{\text {lim }}$ and $n_{\text {lim }}$ is obtained by means of the radius of similar cycles, the inclination angle of which

$$
\operatorname{tg} \beta=\frac{m_{\lim }}{n_{\text {lim }}} \text { or } \operatorname{tg} \beta=\frac{m_{d}}{n_{d}} .
$$

Table 2. The dependence of the factor $a$ and $b$ upon the depth $h$ of the gap

\begin{tabular}{|c|c|c|c|c|c|c|c|c|c|c|c|}
\hline$k=h / r$ & 0.000 & 0.050 & 0.100 & 0.150 & 0.200 & 0.250 & 0.300 & 0.350 & 0.400 & 0.450 & 0.500 \\
\hline$a$ & 1.000 & 1.013 & 1.039 & 1.073 & 1.116 & 1.169 & 1.232 & 1.307 & 1.398 & 1.508 & 1.642 \\
\hline$b$ & 0.721 & 0.745 & 0.791 & 0.853 & 0.933 & 1.033 & 1.158 & 1.316 & 1.517 & 1.777 & 2.121 \\
\hline
\end{tabular}




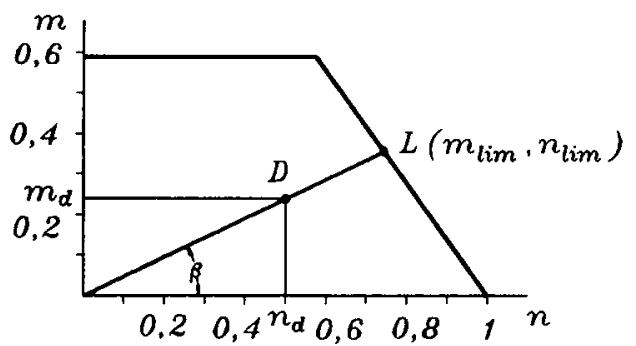

Fig. 3. Limit diagram for case, when $k=0$

The reserve coefficient is identified from quotient

$$
\eta=\frac{m_{l i m}}{m_{d}} \text { or } \eta=\frac{n_{l i m}}{n_{d}}
$$

In case the bolt contains a crack with the depth $h$, another limit diagram shall be drawn up, depending upon the ratio $k$.

\section{Conclusions}

The simplified "additional load" method can be successfully used for the solution of shakedown problems. The results obtained by this approach coincide with the results obtained by the use of the kinematic shakedown theorems which have been earlier developed by the authors. This fact shows the effectiveness of the proposed method. The obtained shakedown diagram enables to determine safety reserve of the bolt as the function of appeared crack depth.

\section{Referenses}

1. Д.АГохфельд. Несущая способность конструктий в условиях теплосмен. М.: Машиностроение, 1970. $250 \mathrm{c}$

2. Д.А.Гохфельд, О.Ф.Чернявский. Несущая способность конструкций при повторных нагружениях. М.: Машиностроение, 1979. $254 \mathrm{c.}$

3. В.Кононов, М.-К.Ляонавичюс, М.Шуктгта, В.Филатов. Применение статической и кинематической теории для оценки приспособляемости резьбовых соединений // Mechanine technologija, XXI, Kaunas, 1993, p. 211-219.

Iteikta 19970130

\section{VARŽTO SU DVIPUSIU PLYŠIU PRISTTAIKOMUMO TYRIMAS PAPILDOMOS APKROVOS METODU}

\section{Leonavičius, M. Šukšta}

\section{Santrauka}

Straipsnyje analizuojamas varžto (smeigès) prisitaikomumas veikiant pastoviai ašinei jègai ir simetriškai kintanđ̌iam lenkimo momentui. Uždavinys sprendžiamas atsižvelgiant i dvipusio, simetriškai išsidèsčiusio plyšio atsiradimą ir vystymąsi. Medžiaga idealiai tampriai plastiska. Sprendimui taikomas papildomos apkrovos metodas. Išnagrinèti vienpusio plastinès deformacijos kaupimosi ir kintamo ženklo plastinio tekèjimo atvejai. Gautos varžto su plintančiu dvipusiu plyšiu prisitaikomumo zonų ribos. Nustatyta varžto atsarga naudojantis prisitaikomumo diagrama îvairiu plyšiu gylių atvejais.

Mindaugas LEONAVIČIUS. Doctor, Assistant Professor. Department of Strength of Materials. Faculty of Fundamental Sciences. Vilnius Gediminas Technical University, 11 Sauletekio Ave, 2040 Vilnius, Lithuania.

Marijonas ŠUKŠTA. Doctor, Assistant Professor. Department of Strength of Materials. Faculty of Fundamental Scinces. Vilnius Gediminas Technical University, 11 Sauletekio Ave, 2040 Vilnius, Lithuania. 